\title{
ВПЛИВ РОЗЧИННИХ РЕЧОВИН НА СТАН ВОДИ В РОСЛИННИХ ТКАНИНАХ ТА КІНЕТИКУ ЇХ СУШІННЯ
}

\author{
Дмитренко Н.В., к.т.н. \\ Інститут технічної теплофізики НАН України, м. Київ, Україна
}

\begin{abstract}
Анотація. В роботі наведено літературні дані щзодо впливу розчинних речовин різного типу на процес та механізм зв'язування води. Порівняно результати визначення стану води у вихідній рослинній сировині, які були отримані з розрахунку за межею гігроскопічності, з результатами прямого експерименту за методом диференціальної сканувальної калориметрії. Встановлено, щуо додаткове зв'язування води, вище ніж отримане з розрахунку, обумовлено наявністю розчинних речовин в рослинному соку. Сумісним аналізом експериментальних кривих зміни стану води, енергограм сушіння, кривих сушіння та кривих швидкості сушіння показано, щчо критичні точки прочесу сушіння знаходяться у відповідності з динамікою зміни стану води в рослинних тканинах та кінетикою зміни питомої теплоти ї̈ випаровування. Встановлено значне зростання енерговитрат на випаровування води вже в другому періоді сушіння. Отримані результати дозволяють стверджувати, що воно відбувається через початок видалення води з гідратних оболонок розчинених речовин. На підгрунті проведеного дослідження уточнено механізм і послідовність видалення води зі зрізів рослинних тканин при сушінні.
\end{abstract}

Ключові слова: рослинні тканини, стан води, розчинні речовини, сушіння.

\section{THE INFLUENCE OF SOLUBLE SUBSTANCES ON THE WATER STATUS IN PLANT TISSUES AND THEIR KINETICS OF DRYING}

\author{
Dmytrenko N.V., Ph.D. \\ Institute of Engineering Thermophysics of NAS of Ukraine, Kyiv, Ukraine
}

\begin{abstract}
The paper presents literary data on the influence of soluble substances of different types on the process and mechanism of water binding in aqueous solutions. Using the method of differential scanning calorimetry, the state of water in the parenchyma tissues of apples and potatoes, in the root crops carrots and beet, and the woody tissues of annual willow shoots was determined. A change in the state of water in these plant tissues during dehydration has been studied. The results of the determination of the state of water in the initial plant raw material obtained from the calorimetric experiment were compared with the results obtained from the calculation according to the hygroscopicity limit according to the assumptions of the sorption isotherms method. It has been established that the amount of bound water in the tissues of plants obtained from the calorimetric experiment is higher than the amount of bound water obtained on the calculation from the limit hygroscopicity of plant tissues. The additional binding of water is due to the presence of soluble substances in plant juice. Using the method of synchronous measurement of mass loss of tissues during drying and the amount of heat consumed for dehydration, an experimental determination of the specific heat of evaporation of water from plant tissues during drying was performed (the drying energy curves have obtained). Using joint analysis curves of change of the state of water in plant tissues, curves of drying energy, drying curves and drying rate curves, it was established that the critical points of the drying process are in accordance with the dynamics of changes in the state of water in plant tissues and the kinetics of the change in the specific heat of evaporation of water. A significant increase in energy consumption for the evaporation of water was detected already in the second drying period of plant tissues. The results obtained allow us to state that this increase in energy costs is due to the beginning of the removal of water from the hydrated shells of substances dissolved in plant juice. On the basis of the research, the mechanism and sequence of water removal from the cut of plant tissues during drying has been made more accurate.
\end{abstract}

Key words: plant tissues, the state of water, soluble substances, drying.

Вступ. Класичні підходи до процесу сушіння колоїдних капілярно-пористих тіл (ККПТ), якими є рослинні тканини, засновані на припущенні, що волога в них утримується силами осмосу, капілярної конденсації та адсорбції на поверхні сухого каркасу тіла [1]. При цьому розглядається вплив на стан води таких характеристик ККПТ як загальна пористість, диференціальна функція розподілу пор за радіусам та iї зміна через деформування матеріалу при сушінні і ніяк не враховується можливість впливу на стан води та процес сушіння певного хімічного складу рослин, зокрема наявності розчинених речовин. 
Формулювання проблеми та аналіз літературних джерел. В теорії та практиці сушіння традиційно вважається, що суттєве зростання енерговитрат при сушінні ККПТ обумовлено видаленням вологи, міцно зв'язаної з каркасом тіла, і відбувається воно на заключному етапі сушіння при видаленні адсорбційно-зв'язаної вологи. При цьому, припускають, що на протязі всього часу видалення вільної води кількість зв'язаної не змінюється і тому збільшення енерговитрат в цей час не відбувається. Однак в рослинних тканинах зв'язування води відбувається в результаті енергетично вигідних взаємодій не тільки 3 нерозчинними речовинами клітинного каркасу рослин, але й з розчиненими в соку речовинами.

3 іонами, на які розпадаються в воді прості розчинні речовини (солі та органічні кислоти), молекули води взаємодіють завдяки кулонівським силам. При цьому, до першого гідратного моношару, якій утворюється навколо полярного іона, може прилягати ще декілька гідратних шарів, зв'язаних менш міцно (рис. 1). Кількість зв'язаних молекул води залежить від природи іона, температури і концентрації розчину. Теплота гідратації іонів становить від 247 КДж/моль $\left(\mathrm{MnO}_{4}^{-}\right)$до 4710 КДж/моль $\left(\mathrm{Al}^{3+}\right)[2]$.

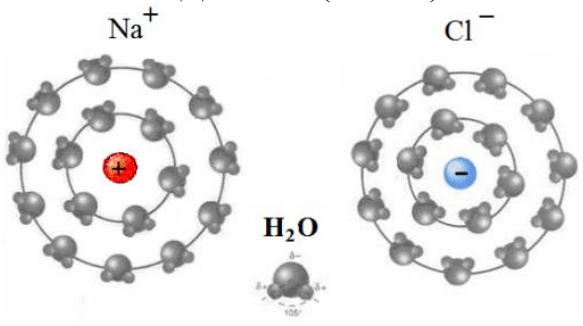

Рис. 1. Утворення гідратних оболонок навколо полярних іонів в водному розчині [3].

Навколо великих, складних розчинних молекул, завдяки тетраедричному розподілу зарядів молекули води і можливості утворення одночасно до чотирьох водневих зв'язків, в тому числі з іншими молекулами води, утворюються водні клатрати (рис. 2). В цукрових розчинах з загальним вмістом води 86 \% кількість гідратної води, що зв'язана 31 г сахарози дорівнює 1 г, а води, що зв'язана 31 г фруктози чи глюкози $-1,2$ г $[4,5]$.<smiles>COC1OCOC1O</smiles>

a)

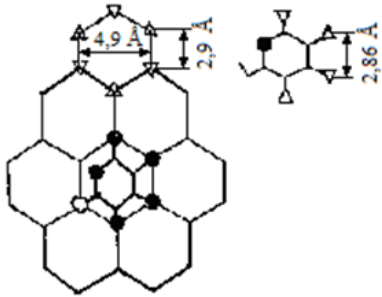

б)

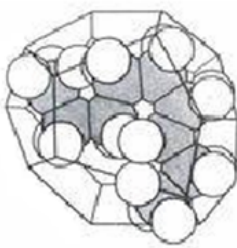

e)

Рис. 2. Утворення водневих зв'язків між 5 молекулами води [6] (a) та молекула вуглеводу у водному клатраті [7] (б), [6] (в).

За класичним підходом ступень зв'язування вологи в ККПТ визначають з розрахунку за ізотермами сорбції $[1,8]$. Так можна визначити кількість вологи яка утримується на межі гігроскопічності (МГ) ККПТ. Кількість зв'язаної вологи у вихідній рослинній сировині з цих даних отримують шляхом переводу кількості води, яка апріорі вся зв'язана після досягненні матеріалом МГ, у відповідну ії кількість на початку сушіння. При цьому припускають, що вся інша вода вище МГ матеріалу - вільна. За мету було поставлено перевірити таке припущення та розрахунки 3 допомогою прямого експериментального визначення кількості зв'язаної води в рослинних тканинах.

Оскільки при зневодненні розчинів стан води і ступень їі зв'язування змінюється, постало, також, питання перевірки впливу розчинних речовин на процес сушіння рослин та його енерговитрати.

Матеріали та методи дослідження. Для порівняння даних щодо стану води у вихідній рослинній сировині, отриманих за допомогою розрахунку з ізотерм сорбції, з результатами, отриманими 3 прямого експерименту, було використано метод диференціальної сканувальної калориметрії (ДСК) [9]. За допомогою диференціального сканувального мікрокалориметра ДСМ-2М здійснювали визначення вмісту вільної води в тканинах за методикою, в основу якої покладена властивість зв'язаної води не зазнавати фазового переходу першого роду при охолодженні. Якщо систему, яка одночасно містить вільну і зв'язану воду охолодити, а потім піддати нагріванню, то на ДСК-кривій буде відображатись пік плавлення тільки вільної води [5]. Оскільки плавлення є процесом рівноважним, площа піка пропорційна теплоті фазового переходу, а, отже, кількості вільної води. Масу зв'язаної води розраховували після визначення загальної маси води у зразку. Загальну масу води у зразку визначали за методом висушування його до постійної маси. 
Для дослідження впливу розчинних речовин на процес сушіння рослинних тканин та енерговитрати на процес випаровування було використано калориметричній комплекс на базі диференціального мікрокалоріметра випаровування ДМКИ-01, якій суміщає в собі можливості диференціальної мікрокалориметрії і термогравіметрії [10]. В приладі реалізовано метод безперервного виміру кількості теплоти, витраченої на випаровування вологи зі зразку в процесі ізотермічного конвективно-кондуктивного сушіння, та одночасного безперервного виміру відповідного зменшення маси зразка.

Для досліджень було використано зрізи нативних рослинних тканин товщиною $1 \ldots 1,5$ мм.

Результати та їх обговорення. Порівняння отриманих за допомогою розрахунку з ізотерм сорбції даних щодо стану води у вихідної рослинної сировині з результатами, отриманими експериментально методом ДСК (табл. 1), показує, що розраховані з МГ значення значно відрізняються від отриманих експериментально. Кількість зв'язаної води в рослинній сировині, що визначена за методом ДСК, значно більша, ніж розрахована з МГ. Тобто, припущення, що вся вода, яка є в рослинних тканинах вище МГ, вільна, не відповідає результатам прямих експериментальних досліджень за методом ДСК.

\section{Стан води у вихідній рослинній сировині}

Таблиця 1

\begin{tabular}{|c|c|c|c|c|}
\hline \multirow{2}{*}{ Тканина } & $\begin{array}{c}\text { Вологість } \\
\text { вихідної } \\
\text { сировини, } \\
\text { \% відн. }\end{array}$ & $\begin{array}{c}\text { Межа гігроскопіч- } \\
\text { ності [11,12], } \\
\text { кг/кг сух. (\% відн.) }\end{array}$ & $\begin{array}{c}\text { Співвідношення вільної/зв’язаної води } \\
\text { у вихідній рослинній сировині, } \\
\text { доля від всієї води }\end{array}$ \\
\cline { 4 - 5 } & розрахунок з МГ & метод ДСК \\
\hline Паренхімна: - яблука & 86,5 & $0,484(32,6)$ & $94,9 / 5,1$ & $79,4 / 20,6$ \\
\hline - картоплі & 75,0 & $0,318(24,1)$ & $89,4 / 10,6$ & $85,2 / 14,8$ \\
\hline Коренеплоду: - моркви & 88,5 & $0,350(26,0)$ & $95,5 / 4,5$ & $85,5 / 14,5$ \\
\hline - столового буряку & 86,5 & $0,352(26,0)$ & $94,5 / 5,5$ & $83,0 / 17,0$ \\
\hline Деревинна верби & 60,0 & $0,281(21,9)$ & $81,3 / 18,7$ & $72,2 / 27,8$ \\
\hline
\end{tabular}

Оскільки класичний розгляд стану води в рослинних матеріалах, заснований на методі сорбції, обмежується розглядом таких механізмів ії зв'язування як адсорбція, осмос та капілярне утримування сухим каркасом тіла [8], можна припустити, що ефект додаткового зв’язування води викликано якимось іншим, не врахованим механізмом. Таким не врахованим механізмом в досліджених рослинних тканинах $\epsilon$ утримування молекул води в гідратних оболонках розчинних речовин клітинного соку. Розчинними речовинами, які утримують воду далеко за МГ, в досліджених рослинних тканинах є цукри, пектини, солі та органічні кислоти (табл. 2). Їх здатність до водоутримування ніяк не залежить, від ступеню пористості тканини, чи радіусу капілярів. Натомість, кількість молекул води в гідратних оболонках цих речовин зростає зі зростанням ступеню розведення розчину $[2,4,5]$. А експериментальні дослідження систем зі свіжим гарбузом показали, що збільшення в них вмісту розчинного пектину в від 4,6 до 5,2 \% призводить до збільшення кількості зв’язаної води від 1 до 1,25 г на 1 г сухої речовини [13].

Таблиця 2

Хімічний склад рослинних тканин $[14,15]$

\begin{tabular}{|c|c|c|c|c|c|c|c|c|c|c|}
\hline \multirow[b]{2}{*}{ Тканина } & \multirow{2}{*}{$\begin{array}{c}\text { Воло- } \\
\text { гість, \% } \\
\text { відн. }\end{array}$} & \multicolumn{9}{|c|}{ г в 100 г сухих речовин } \\
\hline & & $\begin{array}{c}\text { Моно та } \\
\text { дисахариди }\end{array}$ & $\begin{array}{l}\text { Крох- } \\
\text { маль }\end{array}$ & $\begin{array}{c}\text { Целю- } \\
\text { лоза }\end{array}$ & $\begin{array}{l}\text { Геміце- } \\
\text { люлоза }\end{array}$ & Пектини & Білки & Жири & \begin{tabular}{|c} 
Орган. \\
к-ти
\end{tabular} & Зола \\
\hline $\begin{array}{c}\text { Паренхімна } \\
\text { - яблука }\end{array}$ & 86,5 & 66 & 5,9 & 4,4 & 3 & 7,4 & 4,4 & - & 5,2 & 3,7 \\
\hline - картоплі & 75,0 & 7,3 & 73,8 & 4 & 1,2 & 2 & 8 & 1,6 & 0,8 & 0,4 \\
\hline $\begin{array}{c}\text { Коренеплоду } \\
\text { - моркви }\end{array}$ & 88,5 & 60,7 & 0,8 & 10,5 & 2 & 5,2 & 11 & 0,8 & 0,8 & 8 \\
\hline - ст. буряку & 86,5 & 63,1 & - & 6,7 & 6,1 & 10,8 & 8,4 & - & 0,2 & 1,3 \\
\hline \multirow{2}{*}{$\begin{array}{r}\text { Деревинна } \\
\text { верби }\end{array}$} & \multirow{2}{*}{$60-70$} & \multirow{2}{*}{ - } & \multirow{2}{*}{-} & \multirow{2}{*}{47} & \multirow{2}{*}{30} & \multirow[b]{2}{*}{ - } & \multicolumn{2}{|c|}{ Лігнін } & \multicolumn{2}{|c|}{ Екстракт. реч. } \\
\hline & & & & & & & \multicolumn{2}{|c|}{ до 23} & \multicolumn{2}{|c|}{ до 4} \\
\hline
\end{tabular}

Поєднання на одному рисунку (рис. 3) експериментальних залежностей від часу зміни абсолютної вологості рослинних тканин $W^{C}$ при сушінні, швидкості їх сушіння $W^{C} / \Delta \tau$ та перевищення теплоти випаровування води з тканин над теплотою випаровування чистої води $\Delta r$ (на рис. 3 справа) дозволило співставити етапи сушіння з періодами зміни теплоти випаровування, порівняти їх з даними щодо зміни стану води в рослинних тканинах, отриманими методом ДСК (на рис. 3 зліва), та виявити вплив розчинних речовин на процес сушіння рослинних тканин та енерговитрати на випаровування води. 

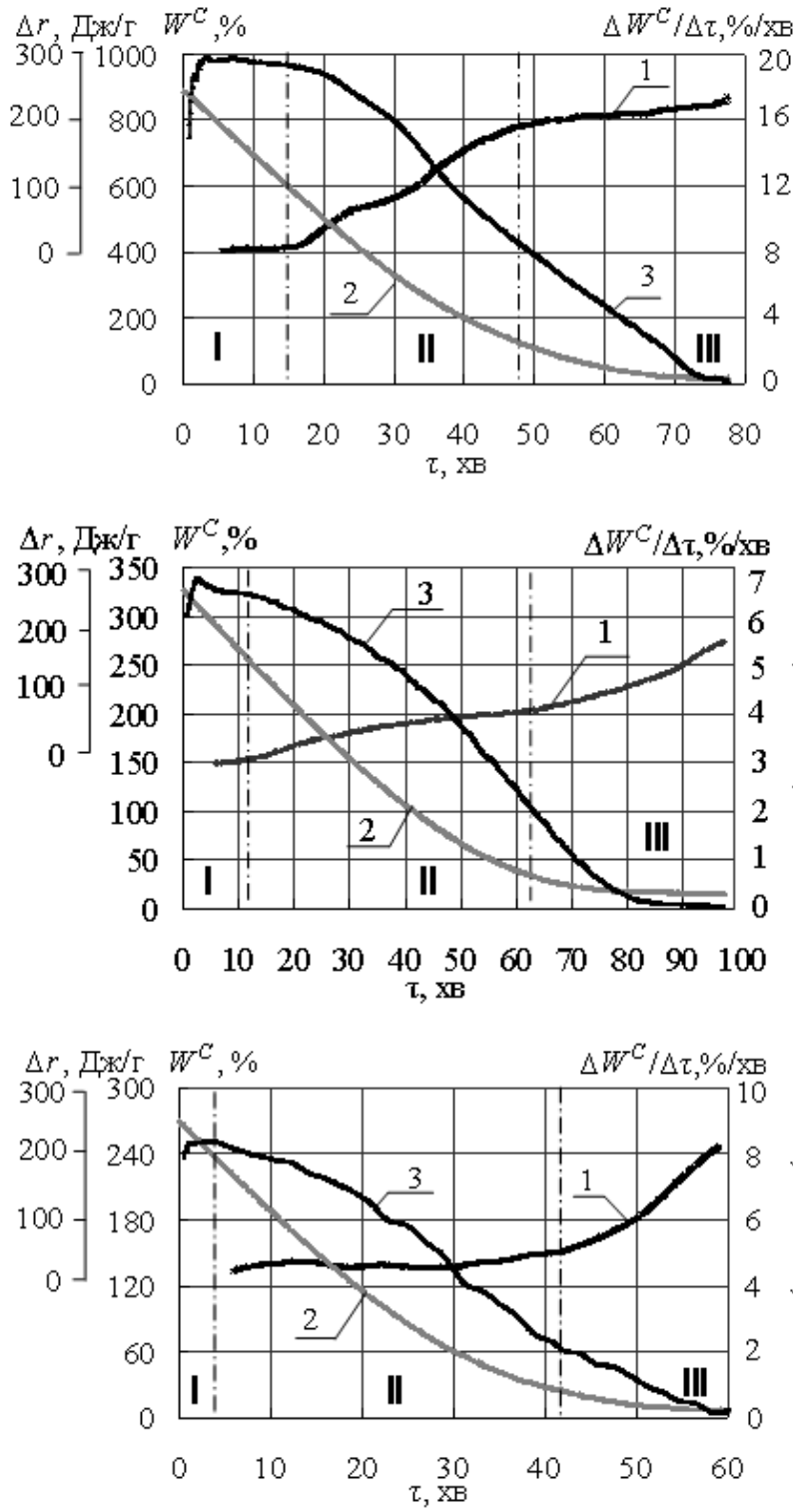

e)

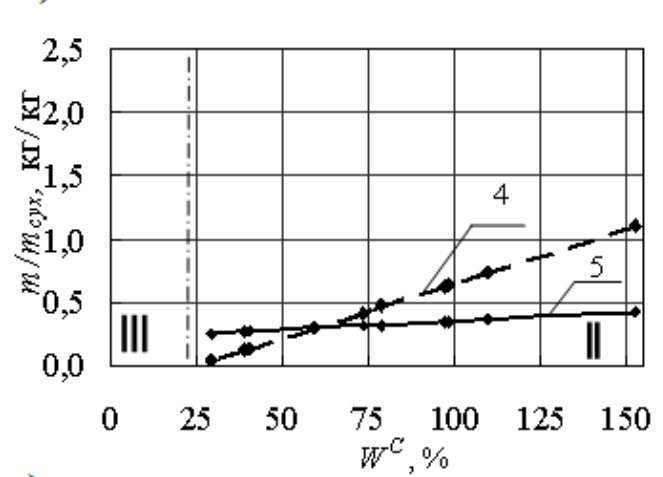

1 - енергограма, 2 - крива сушіння, 3 - крива швидкості сушіння, 4 - вільна вода, 5 - зв'язана вода

Рис. 3. Криві конвективно-кондуктивного сушіння при $60{ }^{\circ} \mathrm{C}$ паренхімних тканин яблука (а), картоплі (б) і деревовидних верби (в) та зміни стану води в них.

Бачимо, що в I періоді сушіння, коли швидкість сушіння постійна, теплота випаровування води з рослинних тканин мало відрізняється від теплоти випаровування чистої води $(\Delta r \sim 0)$, що відповідає незначному зменшенню зв'язаної води у тканинах при значному зменшенні вільної. В II періоді, коли починається спад швидкості сушіння, спостерігається зростання теплоти випаровування (до 10\% для яблука, до 1,5\% для верби), яке обумовлено зростанням долі зв'язаної води у видаленій волозі.

В III періоді, коли вся вільна вода $з$ тканин видалена, відбувається значне зменшення швидкості сушіння при помітному зростанні витрат теплоти на випаровування вже лише зв'язаної води. Хід кривих кінетики і швидкості сушіння досліджених рослинних тканин обумовлений певною послідовністю видалення води різної форми зв'язування (рис. 4) та визначається станом води в тканинах і силою її утримування.

У І періоді сушіння (при його наявності), коли швидкість сушіння близька до постійної величини, а значення теплоти випаровування приблизно дорівнює табличним значенням питомої теплоти випаровування чистої води з вільної поверхні, відбувається зменшення кількості вільної води в рослинних тканинах при незначному зменшенні, або відсутності зменшення, кількості зв'язаної. При температурі вологого матеріалу, що не перевищує температуру термічної деструкції білкових клітинних оболонок, дійсно видаляється вільна вода шляхом випаровування з поверхні рідин міжклітинних проміжків та клітин, розітнутих під час приготування зразка. 


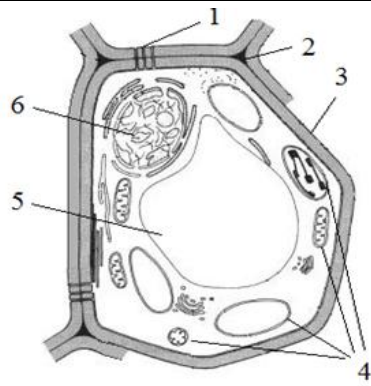

a)

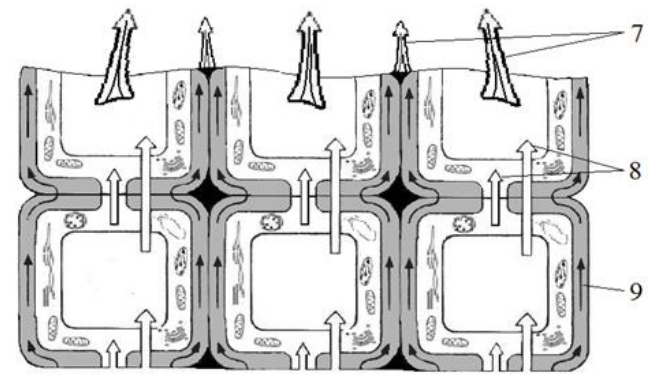

б)

1 -міжклітинні ц̧итоплазматичні канали; 2 -міжклітинні проміжки; 3 - клітинна оболонка;

4 - органели; 5 - вакуоля; 6 - ядро; 7 - випаровування води з поверхні рідини міжклітинних проміжків та з соку клітин, розітнутих перед сушінням; 8 - міграція та осмотична дифузія води клітинного соку; 9 -міграчія та осмотична дифузія води клітинних оболонок

Рис. 4. Рослинна клітина (а) та схема видалення води зі зрізу рослинної тканини при сушінні (б).

У II періоді сушіння, коли швидкість видалення води плавно зменшується на фоні зростання питомої теплоти випаровування понад табличним значенням теплоти пароутворення чистої води, відбувається гальмування видалення води завдяки наростаючому опору капілярної міграції та осмотичної дифузії вологи через збігання тканин. Це згідно традиційних уявлень щодо сушіння ККПТ [1]. Також, згідно традиційних уявлень, питома теплота випаровування повинна залишатися незмінною, бо, коли концентрація позаклітинного розчину перевищує концентрацію внутріклітинного, до поверхні, за рахунок осмосу, починає дифундувати та випаровуватися вільна вода внутріклітинного розчину. У випадку вибраних для дослідження рослинних тканини дегідратація, в цьому періоді, супроводжується досить значним зростанням питомої теплоти випаровування, обумовленим збільшенням частки зв'язаної води у волозі, яка видаляється. Тобто, II період сушіння можна пов'язати ще й з початком видалення води з гідратних оболонок розчинених в клітинному соку речовин при поступовому зростанні концентрації рослинного соку.

III період сушіння рослинних тканин наступає після видалення всієї вільної води. Цілком у відповідності з традиційними уявленнями щодо сушіння ККПТ тут відбувається стрімке спадання швидкості сушіння на фоні швидкого приросту витрат теплоти на випаровування, пов'язаного з початком видалення виключно зв'язаної води зі все глибших шарів, адсорбованих біополімерами клітинних оболонок, та 3 гідратних координаційних сфер розчинених речовин. Видалення мономолекулярних шарів води наприкінці цього періоду супроводжується ще більш різкім зростанням питомої теплоти її випаровування при падінні до мінімуму швидкості сушіння.

Висновки. Існуючи методи напівемпіричного розрахунку кількості зв'язаної води враховують лише фізичну структуру тканин, але не наявність у них розчинених речовин. Тому розрахункові значення кількості зв'язаної води в рослинних тканинах відрізняються від значень, отриманих за допомогою безпосередніх експериментальних вимірів.

Сумісний аналіз стану води, енергограм, кривих сушіння та кривих швидкості сушіння показав, що критичні точки процесу сушіння знаходяться у відповідності з динамікою зміни стану води в рослинних тканинах та кінетикою зміни питомої теплоти ії випаровування.

Отримані результати дозволяють стверджувати, що при зневодненні рослинних тканин уже в другому періоді їх сушіння відбувається значне зростання енерговитрат через початок видалення води 3 гідратних оболонок розчинених в рослинному соку речовин.

\section{Література}

1. Лыков А. В. Теория сушки. - М.: «Энергия», 1968. - 472 с.

2. Зайцев И.Д., Асеев Г.Г. Физико-химические свойства бинарных и многокомпонентных растворов неорганических веществ: справочное издание. - М.: «Химия», 1988. - $416 \mathrm{c}$.

3. Мосин О.В. Способность воды к растворению. Сайт о8ode.ru. - Режим доступа: http://www.o8ode.ru/article/water/

4. Михайлик В.А. Экспериментальное исследование гидратации сахарозы // Наукові праці Одеської національної академії харчових технологій. - 2006. - Вип.28, т.2. - С. 370-374.

5. Михайлик В.А., Давидова О.О., Манк В.В. Дослідження гідратації D-глюкози та D-фруктози // Проблеми та перспективи створення і впровадження нових ресурсо- та енергоощадних технологій, обладнання в галузях харчової і переробної промисловості : матеріали VI міжнародн. наук.-техн. конф., Київ, 19-21 жовт. 1999 р. : у 3 ч. - К.: «УДУХТ», 2000. - Ч.1. - С. 106.

6. Исаков В.Т. Естественное и искусственное структурирование воды. Сайт o8ode.ru. - Режим доступа: http://www.o8ode.ru/article/learn/water_structure.htm

7. Фрэнкс Ф. Вода, лед и растворы простых молекул // Вода в пищевых продуктах; под ред. Р.Б. Докуорта; пер. с англ. - М.: «Пищевая промышленность», 1980. - С. 14-32.

8. Брунауер С. Адсорбция газов и паров. - М.: «Гос. изд-во иностранной литературы», 1948. -768.

9. Симатос Д., Фоур М., Бонжур И., Коуч М. Применение дифференциального термического анализа и дифференциальной сканирующей калориметрии при изучении воды в пищевых продуктах / Вода в пищевых продуктах. Под ред. Р.Б. Докуорта. - М.: «Пищевая промышленность», 1980. - С. 156-170. 
10. Калориметричний пристрій для визначення питомої теплоти випаровування вологи і органічних рідин з матеріалів: пат. 84075 Україна: МПК ${ }^{8}$ G01 N25/26, G01 N25/28. № а200613266; заявл. 15.12.06; опубл. 10.09.08.

11. Никитина Л.М. Таблицы равновесного удельного влагосодержания и энергия связи влаги с материалами. - М.-Л.: «Госэнергоиздат», 1963.- $176 \mathrm{c}$.

12. Сушка древесины: справочник / Составители С. Алюшин и др. - К.: «Тристан», 2004. - 448 с.

13. Згурський А.В., Поліщук Г.Є., Кропивницька І.О. Перерозподіл пектинових речовин в овочевій сировині при виробництві морозива // Харчова промисловість. - 2011. - № 10. - С. 50-55.

14. Химический состав пищевых продуктов : справочные таблицы : в 2 кн. / Под ред. И.М. Скурихина и М.Н. Волгарева. - М.: «Агропромиздат», 1987.

15. Гупало О. П., Тушницький О. П. Хімія деревини : навч. посібник - К.: «Знання», 2008. - 276 с.

\title{
References
}

1. Lykov A. V. (1968). Teoriya sushki. Moscow: Energiya, 472.

2. Zaytsev I.D., Aseev G.G. (1988). Fiziko-khimicheskie svoystva binarnykh i mnogokomponentnykh rastvorov neorganicheskikh veshchestv: spravochnoe izdanie. Moscow: Khimiya, 416

3. Mosin O.V. Sposobnost vody k rastvoreniyu. Sayt o8ode.ru. - Available at: http://www.o8ode.ru/article/water/

4. Mikhaylik V.A. (2006). Eksperimentalnoe issledovanie gidratatsii sakharozy. Naukovi pratsi Odeskoï natsionalnoï akademiï kharchovikh tekhnologiy, no. 28, vol. 2, pp. 370-374.

5. Mikhaylik V.A., Davidova O.O., Mank V.V. (2000). Doslidzhennya gidratatsii D-glyukozi ta D-fruktozi. Proceedings of the Problemi ta perspektivi stvorennya i vprovadzhennya novikh resurso- ta energooshchadnikh tekhnologiy, obladnannya $\mathrm{v}$ galuzyakh kharchovoï i pererobnoï promislovosti (Ukraine, Kiev, October 19-21, 1999). Kiev: UDUKhT, vol.1, pp. 106.

6. Isakov V.T. Yestestvennoe $\mathrm{i}$ iskusstvennoe strukturirovanie vody. Sayt o8ode.ru. - Available at: http://www.o8ode.ru/article/learn/water_structure.htm

7. Frenks F. (1980). Voda, led i rastvory prostykh molekul. Voda v pishchevykh produktakh, eds. R.B. Dokuorta. Moscow: Pishchevaya promyshlennost, pp. 14-32

8. Brunauer S. (1948). Adsorbtsiya gazov i parov. Moscow: Gos. izdatelstvo inostrannoy literatury, 768.

9. Simatos D., Four M., Bonzhur I., Kouch M. (1980). Primenenie differentsialnogo termicheskogo analiza i differentsialnoy skaniruyushchey kalorimetrii pri izuchenii vody v pishchevykh produktakh. Voda v pishchevykh produktakh, eds. R.B. Dokuorta. Moscow: Pishchevaya promyshlennost, pp. 156-170.

10. Snezhkin Yu.F., Dekusha L.V., Dubovikova N.S., Grishchenko T.G., Vorobyov L.Y., Boryak L.A. (2008). UKR. Patent No. 84075.

11. Nikitina L.M. (1963). Tablitsy ravnovesnogo udelnogo vlagosoderzhaniya i energiya svyazi vlagi s materialami. - MoscowLeningrad: Gosenergoizdat, 176.

12. Alyushin S. et al. (2004). Sushka drevesiny: spravochnik. Kiev: Tristan, 448.

13. Zgurskiy A.V., Polishchuk G.C., Kropivnitska I.O. (2011). Pererozpodil pektinovikh rechovin v ovocheviy sirovini pri virobnitstvi moroziva . Kharchova promislovist, no. 10, pp. 50-55

14. Skurikhin I.M., Volgarev M.N. (1987). Khimicheskiy sostav pishchevykh produktov. Spravochnye tablitsy, 2 vol. Moscow: Agropromizdat.

15. Gupalo O. P., Tushnitskiy O. P. (2008). Khimiya derevini. Navchflnyi posibnik. Kiev: Znannya, 276.

\section{ДІЄТИЧНА ДОБАВКА ІМУНОТРОПНОЇ ДІЇ НА ОСНОВІ ПРОДУКТІВ ДЕСТРУКЦЇ̈ ПРОБІОТИЧНИХ БАКТЕРІАЛЬНИХ КУЛЬТУР}

\author{
Капустян А. І., к.т.н., доцент, Черно Н. К., д.т.н., професор \\ Одеська національна академія харчових технологій, м. Одеса
}

\begin{abstract}
Анотація. У роботі розглянуто можливість отримання імунотропної дієтичної добавки на основі низькомолекулярних продуктів деградації пептидогліканів клітинних стінок пробіотичних бактерій. Встановлено раціональні режими автолізу біомаси як первинного етапу деструкиії пептидогліканів бактеріальних клітинних стінок. Показано, щзо найбільш інтенсивний лізис клітин відбувається при експозииії культуральної рідини при 90 ${ }^{\circ}$ протягом 15 хв після 8-ї години культивування, про щчо свідчить ма-

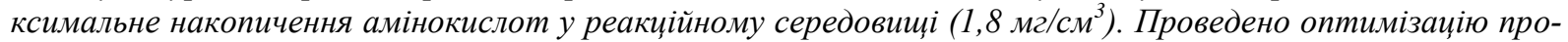
иесу деструкиії пептидогліканів бактеріальних клітин, які піддавали лізису, ферментним препаратом панкреатином. Ефективність ферментолізу визначали за накопиченням імунотропних низькомолекулярних пептидів залежно від концентрації ферменту $\left(C_{E}\right)$, субстрату $\left(C_{S}\right)$ в реакційній суміші та тривало-

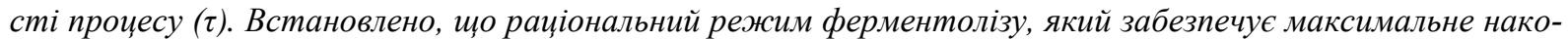
пичення низькомолекулярних пептидів $(0,569$ мг/см², досягається за наступних значень факторів: $C_{E}=12,5 \mathrm{мг} / \mathrm{cm}^{3}, C_{S}=70,0 \mathrm{мг} / \mathrm{cm}^{3}, \tau=245,6$ хв. Зразок низькомолекулярних пептидів, отриманий за раціональних режимів деструкції, досліджено методом IЧ-спектроскопї. Встановлено, щзо у його IЧ-спектрі присутні смуги поглинання, які відповідають коливанням аміногруп, пептидних зв'язків, піранозної форми глюкози, залишки якої входять до складу мурамової кислоти, та N-ацетилглюкозаміну пептидоглікану. Приведено загальну схему, що ілюструє послідовність прочесів виробництва імунотропної дієтичної
\end{abstract}

